in soft rubber which at great depths is highly compressed. By their use, visibility is quite good at a depth of $400 \mathrm{ft}$. and photographs have been obtained at this depth. They are also used for salvage operations. Lamps at voltages which give them a life of about an hour only are used for photographic work. At still higher pressures we get the 'photoflash' lamp which is only used for instantaneous flashes. When used in a bulb of special blue-coloured glass, the blinding effect is negligible and the photographic effect is little impaired. In Europe, remarkable progress has been made in developing electric discharge lamps. In the United States, sodium and mercury lamps are used; the latter is the more popular for interior lighting. The Statue of Liberty in New York Harbour is flood-lighted, the intensity of the illumination being 30 foot-candles. Golf courses are now being lighted and playing at night is proving popular. A few courses are lighted by filament lamps, the consumption being 5-10 kilowatts per hole. Steam and sailing yachts are sometimes flood-lighted, the canvas and the funnels being illuminated. As well as being decorative, this adds to their safety. One of the chief uses of ultra-violet energy is for the purification of liquids. By means of a cinema film, the purification of water by killing the bacteria with ultra-violet rays was shown.

\section{Steam Tables}

WHEN a conference of American engineers and physicists decided in 1921 on a research programme to produce more accurate data on the properties of steam, investigation of the properties of saturated steam was assigned to the National Bureau of Standards. Recent research both in America and in Great Britain has increased the available data, and in the July issue of the Journal of Research of the Bureau, Messrs. N. S. Osborne and C. H. Meyers give the results of their examination of it in the form of tables of the saturation pressure and of its rate of change with temperature in both atmospheres and kilograms per square $\mathrm{cm}$. units for each degree Centigrade and Fahrenheit between $-5^{\circ} \mathrm{C}$. and $374^{\circ} \mathrm{C}$., the critical point being $374 \cdot 1^{\circ} \mathrm{C}$. The results of Holborn, Scheel and Henning of the Reichsanstalt, Egerton and Callendar, Osborne and his colleagues of the Bureau, Keyes and his colleagues of the Massachusetts Institute of Technology have all been utilised. At temperatures below $200^{\circ} \mathrm{C}$. they differ very little from each other, and even near the critical temperature the differences are less than $0 \cdot 1$ per cent of the pressure, which is nearly 218 atmospheres. Both saturation pressure and its variation with temperature are expressed in terms of absolute temperature by empirical formulæ modified from those in common use, but it is not intended that for practical purposes the formulæ should replace the tables.

\section{The University in the New Age}

Mr. Maycock, in a contribution to the Hibbert Journal (32, No. 4), hopes that the universities may save us from an anarchic and materialistic society "where all will live for the moment in a chaos of pure sensation". This salvation will be possible only if the universities have due reverence for the traditions of their past, and for the value and dignity of learming. A survey of their history shows that they have to-day a great opportunity. They are once more as influential as they were in the Middle Ages; all that is wanting is an equivalent of the medieval synthesis. Mr. Maycock sees hope for this in the present-day pre-occupation with the social sciences, since these lead more readily to integration than the nineteenth century development of physical science. Over-specialisation has put learning out of touch with life, and has endangered our social order, and this the universities can remedy, not by becoming technical schools but by teaching an attitude to knowledge; the new age needs to recover the spiritual values of the Middle Ages, and, like Aquinas, to call those men wise "who control things rightly and set them in order".

\section{Nations and the Public Health}

INTERNATIONAL co-operation in public health is assuming much importance at the present time, and formed the subject of Sir George Buchanan's Milroy Lectures, delivered before the Royal College of Physicians, London, in February and March last (reprinted from the Lancet, April and May, 1934, pp. 879, 935, and 992). After some introductory remarks respecting the Rockefeller Foundation, the Red Cross and League of Red Cross Societies, he proceeds to survey some of the public health activities of the League of Nations, and of the Office International d'Hygiene Publique, Paris. The former have included health missions to various countries, international regulation of opium and drugs of addiction, statistics and radiological treatment of cancer, standardisation of biological products such as therapeutic sera, and inquiries into the laboratory procedures employed in the Wassermann test for syphilis. At the International Office in Paris, a permanent committee of delegates, representing fifty-one Governments, meets in regular half-yearly sessions, and is concerned with the prevention of plague, cholera and some other communicable diseases. It drafted the International Sanitary Convention, 1926, which deals with quarantine and de-ratisation of ships, it co-ordinates the sanitary control of the Mecca Pilgrimage, and it drew up the International Sanitary Convention for Aerial Navigation, 1933, which has already been signed by many nations. These international meetings also serve to establish a personal relationship with fellow-workers overseas and in foreign countries, and are invaluable as a time-saver when dealing with common problems.

\section{Meteorology of India}

IN a lecture delivered to the Royal Society of Arts on April 13, an account of which appears in the Journal of the Society $(82$, No. 4256), Mr. J. H. Field discussed the meteorology of India. In his lecture, Mr. Field gave interesting accounts of recent developments, such as the detection of cyclones at sea by the indications of seismographs, a subject developed 
by Dr. S. K. Banerji with the aid of a Milne-Shaw seismograph located in Bombay, and also of recent researches into the system of upper winds over India. At the present time, maps are prepared daily showing the wind systems at seven different levels between 500 metres and 6,000 metres above the ground. These maps are of great service to aviation. Speaking of the dangers to flying in India, Mr. Field pointed out that these include most of those encountered in Europe with the addition of dust storms, and of hail storms that at their worst probably surpass any that occur in Europe; he spoke of cases where hail stones of at least five inches diameter have destroyed Indian villages and killed every living creature in them. A point that emerged very clearly was the inadequacy of the financial provision for dealing with the requirements of aviation over the Indian section of the air route from England to Australia. The service was described as a "skeleton provision, materially below the standards recommended in the International Air Convention". This, fortunately, can be regarded as a matter that in the forward march of aviation must inevitably be set right, sooner or later. It is to be hoped that realisation of the importance of more complete meteorological information will not be delayed until after numerous fatal accidents have directed public attention to the subject.

\section{Plant Collecting in Asia}

Mr. F. KIngdon Ward contributes the first of a series of articles about his twelfth expedition in Asia to the Gardeners' Chronicle of August 4. His object was, of course, to find new plants with which to enhance the beauty of gardens, and to add to the knowledge of the systematic botany of Asia. He was accompanied on part of the journey by $\mathrm{Mr}$. R. Kaulbach, and by Mr. Brooks-Carrington, who is a kinematographer sent out by Ray-Col British Corporation Ltd. Ten thousand feet of colour film illustrating "Plant Hunting on the Edge of the World" have been prepared, and will shortly be on view in Great Britain. Mr. Kingdon Ward's journey began at Calcutta on February 25, 1933 ; thence he journeyed to Sadiya by way of Shillong, the capital of Assam. From Sadiya he went to Rima and beyond, to the snow range, entering the unexplored regions beyond Shugden Gompa. Returning to Zayul, he explored that province, and finally returned from Tibet to Assam via the Delei valley. A number of new plants were collected on the expedition, and will be described in subsequent instalments of the narrative, which is also highly descriptive of the country traversed.

\section{Pollen Carried by Dust Storms}

IN connexion with a note published in NATURE of June 16, p. 905, on the high proportion of pollen found in the dust storms experienced this year in the United States, Mr. K. Biswas, curator of the Herbarium, Royal Botanic Garden, Calcutta, directs attention to the "Puspa-bristi" (rain of flowers) frequently noticed in India. During late February and Mareh, which is the flowering period of a large number of trees in the plains and terai of the Eastern Himalayas, the pollen seems often to be carried up to high levels in the hot air and then distributed over a wide area by dust storms. The pollen settles later with the dew or rain in drops of liquid, which dry upon the foliage of the plants leaving residues of pollen grains.

\section{Useful Birds}

THE Royal Society for the Protection of Birds has just added to its attractive series of coloured foodcharts of birds, pictorial representations of the proportions of useful, harmful and neutral work (so far as human interests are concerned) done by the jackdaw, kestrel, nightjar and yellow-hammer. The cards, which are issued at $4 d$. each post free, or $4 s .4 d$. for the series of 16, are telling exhibits for use in museums or school-rooms. Recently the Ministry of Agriculture and Fisheries has issued Advisory Leaflets describing the characteristics and habits of the barn owl, woodpeckers, starling, swallow, martins and swift, lapwing and wagtails. A leaflet in the same series describes some simple nest boxes for the encouragement of the breeding of useful birds in gardens, orchards and allotments. They cost 1 d. net each.

\section{Dinosaur Discovery in Wyoming}

Dr. Barnum Brown, leader of the American Museum Sinclair Dinosaur Expedition, has discovered (according to Science Service, Washington, D.C.) an extraordinarily rich collection of fossil dinosaurs in Red Gulch Quarry, twenty-five miles east of Greybull, Wyoming. The number of skeletons unearthed up to the end of July was twelve, and Dr. Brown believes that they represent the remains of a herd of gigantic sauropod dinosaurs, caught in drying lakes and swamps, during an extended drought in the area some 125 millions of years ago.

\section{An Automatic Firedamp Recorder}

The Safety in Mines Research Board has issued as Paper No. 86 an account of an automatic firedamp recorder, reference to which has already been made and a picture of the plant published in the twelfth annual report of the Safety in Mines Research Board, whilst the recorder had previously been described in the Transactions of the Institution of Mining En. gineers. The present paper, however, gives the construction in more detail than either of the previous publications above referred to. The paper is by Mr. H. Lloyd, who designed the instrument in question.

\section{Stemming Materials}

The Safety in Mines Research Board has just published Paper No. 84 dealing with stemming materials and written by Prof. J. A. S. Ritson and Mr. H. Stafford. This paper is practically a resumé of a number of papers and observations which Prof. Ritson and his colleagues have been carrying out for a number of years. The first paper was published by them in the Transactions of the Institution of 